\title{
Use of the effluent from biogas production for cultivation of Spirulina
}

\author{
Malin Hultberg ${ }^{1}$ (1) Olle Lind $^{1}$ - Göran Birgersson ${ }^{2} \cdot$ Håkan Asp ${ }^{1}$
}

Received: 25 August 2016/Accepted: 12 December 2016/Published online: 26 December 2016

(C) The Author(s) 2016. This article is published with open access at Springerlink.com

\begin{abstract}
The effluent from the biogas process was tested as a nutrient source during cultivation of the protein-rich and edible microalgae Spirulina (Arthrospira platensis) and compared with conventional Spirulina medium. Equal biomass production was observed until late exponential phase and no significant differences could be observed between the treatments in protein amount, amino acid composition, and total lipid concentration. The concentration of the pigment phycocyanin differed significantly between Spirulina medium and the effluent-based medium $\left(63.3 \pm 11.7\right.$ and $86.2 \pm 1.9 \mathrm{mg} \mathrm{g}^{-1}, \quad$ respectively $)$ Slightly higher concentrations of saturated fatty acids, mainly palmitic acid, were observed in the biomass produced in Spirulina medium than in that produced in the effluent-based medium. In the biomass produced in the effluent-based medium, the cadmium concentration was $0.07 \pm 0.05 \mathrm{mg} \mathrm{kg}^{-1}$ of dry weight, whereas it was below the detection limit in the biomass produced in Spirulina medium. There is a need to identify new food and feed resources and a possible future scenario is to integrate Spirulina production into the biogas plant for protein production as it contains more than $60 \%$ of protein on dry weight basis. In that scenario, it is important to control heavy metal concentrations in the biogas slurry fed to Spirulina.
\end{abstract}

Malin Hultberg

Malin.Hultberg@slu.se

1 Department of Biosystems and Technology, Swedish University of Agricultural Sciences, P.O. Box 103, 23053 Alnarp, Sweden

2 Department of Plant Protection Biology, Swedish University of Agricultural Sciences, Alnarp, Sweden
Keywords Anaerobic digestate effluent - Arthrospira platensis $\cdot$ Biofertiliser $\cdot$ Microalgae $\cdot$ Nutrient recycling

\section{Introduction}

The world's population is increasing rapidly, and there is a need to identify new food and feed resources. One possibility to meet the need for high-quality protein is through increased production of the microorganism known as Spirulina. Taxonomically, Spirulina generally comprises the species Arthrospira platensis and A. maxima within the genus Arthrospira [1]. However, the term Spirulina is commonly used for historical reasons. Spirulina is a multicellular edible cyanobacterium, capable of photosynthesis, that is traditionally used as a food source in Mexico and parts of Africa. Dried Spirulina biomass contains approximately $60 \%$ protein, which is high compared with traditional protein crops, such as soybean. Spirulina contains all essential amino acids and also high-quality lipids, with a substantial amount of polyunsaturated fatty acids [2]. It should also be pointed out that in contrast to traditional crops, such as soybean, Spirulina does not require arable land for its production. Commercial production is normally performed in open ponds [3]. Spirulina is, therefore, suitable for food production in the vicinity of nutrient-rich wastewater streams, regardless of the availability of soil, e.g., in urban or peri-urban areas.

During production of Spirulina, and also of other photosynthetic microorganisms, macronutrients, such as nitrogen and phosphorus, are commonly supplied in the form of commercial inorganic fertiliser. Replacing these inorganic chemical compounds with residue streams would increase both sustainability and economics during production [4]. An important aspect is that global phosphorus 
reserves are declining, and thus, phosphorus recycling is crucial [5]. Therefore, the economic feasibility of Spirulina production on organic waste sources can be expected to increase when the supply of inorganic phosphorus decreases. Studies on cultivation of Spirulina with residue streams as the nutrient source have generally reported good results [6]. A potential explanation for this is that cultivation of Spirulina has traditionally been based on photoautotrophy. However, higher growth rate has been demonstrated under conditions allowing mixotrophic growth [7]. This type of growth, where the microorganisms retrieve energy from organic carbon sources and also from light, can be expected in a medium based on residue streams, since mineral nutrients and organic carbon will be present.

In parallel with the increase in the world's population, there is a growing need for energy and increased interest in renewable energy sources [8]. One alternative is anaerobic waste treatment, a net energy producing technology through production of biogas during anaerobic digestion of the waste. This technology is now used on a large scale in many countries for treatment of different types of agroindustrial wastes [9]. Depending on the initial substrate/s added in the anaerobic process, the effluent from the biogas process is often transferred back to agriculture and used as a biofertiliser. At small-scale level, biogas plants have been integrated with greenhouse crop production through the multifunctional use of anaerobic digestion reactors, in which heating from combustion of the methane produced and fertilisation with digestate and carbon dioxide have synergistically increased the productivity of the system $[10,11]$. The same principle of integration could possibly be applicable to production of Spirulina, through the use of digestate as a nutrient source and methane combustion for heating and carbon dioxide biofixation in closed photobioreactors [12]. Furthermore, tubular photobioreactors would allow for high light and space use efficiency due to the large illumination surface and vertical orientation [13], making such a Spirulina biomass producing system suitable in an urban setting, where production of biodegradable waste is high.

In the present study, the effluent from a biogas plant, processing plant residues only, was tested as a nutrient source during cultivation of Spirulina and compared with a conventional Spirulina medium. The growth rate of Spirulina and biochemical factors in the biomass, such as protein concentration and amino acid composition, lipid composition, and production of phycocyanin, were analysed. Accumulation of cadmium was also determined, as the presence of potential contaminates and their risk for transmission into the food chain must be considered in any residue-based process.

\section{Materials and methods}

\section{Microorganism and media}

Spirulina platensis LB 2340 was obtained from UTEX Culture Collection of Algae at the University of Texas, Austin, USA. The strain was routinely cultivated in Spirulina medium with the following composition: $\left(\mathrm{g} \mathrm{L}^{-1}\right)$ $\mathrm{NaHCO}_{3}$ 13.6, $\mathrm{Na}_{2} \mathrm{CO}_{3}$ 4.0, $\mathrm{K}_{2} \mathrm{HPO}_{4}$ 0.5, $\mathrm{NaNO}_{3}$ 2.5, $\mathrm{K}_{2} \mathrm{SO}_{4} 1.0, \mathrm{NaCl} 1.0, \mathrm{MgSO}_{4} \cdot 7 \mathrm{H}_{2} \mathrm{O} 0.2 \mathrm{~g}, \mathrm{CaCl}_{2} \cdot 2 \mathrm{H}_{2} \mathrm{O}$ $0.04 \mathrm{~g},(\mathrm{mg} / \mathrm{l}) \mathrm{Na}_{2}$ EDTA $2 \mathrm{H}_{2} \mathrm{O} \quad 4.60, \mathrm{FeCl}_{3} \cdot 6 \mathrm{H}_{2} \mathrm{O} 0.60$, $\mathrm{MnCl}_{2} \cdot 4 \mathrm{H}_{2} \mathrm{O} \quad 0.26, \mathrm{ZnCl}_{2} \quad 0.03, \mathrm{CoCl}_{2} \cdot 6 \mathrm{H}_{2} \mathrm{O} \quad 0.03, \mathrm{Na}_{2}$ $\mathrm{MoO}_{4} \cdot 2 \mathrm{H}_{2} \mathrm{O} 0.04, \mathrm{CuSO}_{4} \cdot 5 \mathrm{H}_{2} \mathrm{O} 0.02, \mathrm{ZnSO}_{4} \cdot 7 \mathrm{H}_{2} \mathrm{O} 0.04$, $\mathrm{H}_{3} \mathrm{BO}_{3}$ 0.06, and cyanocobalamin 0.14 . The composition corresponded to the following concentration of macronutrients: $\left(\mathrm{mg} \mathrm{L}^{-1}\right) \mathrm{N}-\mathrm{NO}_{3}$ 411.6, P 89.0, K 673.2, Ca 10.9, S 210.2, and $\mathrm{Mg} 19.7$.

Effluent from the biogas process was obtained from Jordberga Biogas, Trelleborg, a commercial biogas plant in southern Sweden producing biogas and biofertiliser based on plant residues obtained from local agriculture. The effluent was filtered in polyamide filters (Sintab AB, Sweden) in several steps with a final mesh size of $5 \mu \mathrm{m}$ to remove particles. The concentrations of nitrate and ammonium in the filtered effluent were determined colorimetrically on an automatic analyser (TRAACS 800 Bran-Luebbe) using the Berthelot reaction for ammonium and the cadmium reduction method for nitrate [14]. The concentrations of phosphorus and other nutrients were analysed by inductively coupled plasma optical emission spectrometry (ICP-OES) according to ISO 11885.

The filtered effluent was used in a carbonate buffer, $\mathrm{pH}$ 9.2, composed of $13.6 \mathrm{~g} \mathrm{~L}^{-1} \mathrm{NaHCO}_{3}$ and $4.0 \mathrm{~g} \mathrm{~L}^{-1}$ $\mathrm{Na}_{2} \mathrm{CO}_{3}$. In the experiments, a concentration of $1.5 \%(\mathrm{v} / \mathrm{v})$ of the effluent was added at the start as a nutrient source, a similar volume of effluent was added after 3 days of growth, and a final addition of $3 \%(\mathrm{v} / \mathrm{v})$ of the initial volume was added after 6 days of growth. Thus, a total of $6 \%$ effluent was used in the medium, which corresponded to an added macronutrient concentration of: $\left(\mathrm{mg} \mathrm{L}^{-1}\right) \mathrm{N}-$ $\mathrm{NH}_{4}$ 93.0, P 3.9, K 93.0, Ca 16.9, S 3.5, and Mg 2.1. The effluent was added in a stepwise manner to allow light transmission during algal growth.

\section{Experimental setup}

The experimental setup included the effluent-based medium described above and the control treatment based on Spirulina medium. All experiments were performed in a greenhouse with a $16 \mathrm{~h} / 8 \mathrm{~h}$ day/night regime with an added light intensity of $100 \mu \mathrm{mol} \mathrm{m} \mathrm{m}^{-2} \mathrm{~s}^{-1}$ and the temperature set to $25^{\circ} \mathrm{C}$. The experiments were performed as 
batch cultures with a total volume of $3 \mathrm{~L}$ and were continuously stirred at a speed of $100 \mathrm{rpm}$. For inoculation, an inoculum size comprising 10\% (v/v) of a 7-day-old culture cultivated in Spirulina medium was added. The inoculum corresponded to $230 \pm 6 \mathrm{mg} \mathrm{L}^{-1}$ dry weight (DW) of biomass. For evaluation of biomass productivity, samples were taken on days $3,5,7$, and 10. For evaluation of protein concentration, amino acid composition, total lipids and lipid quality, production of phycocyanin and allophycocyanin and cadmium uptake, and samples were taken on day 6 . These analyses are described in the following.

\section{Analyses}

\section{Biomass production}

The algal biomass was collected by filtration through nylon filters with a mesh size of $10 \mu \mathrm{m}$ and washed once with an equal amount of distilled water. Before and after filtration, the filters were dried in an oven at $60{ }^{\circ} \mathrm{C}$ until constant weight, to determine the dry weight of the algal biomass collected.

\section{Biochemical composition}

For analysis of the biochemical composition, the algal biomass was harvested at day 6 by filtration as described above. The washed biomass was then frozen at $-80{ }^{\circ} \mathrm{C}$, freeze-dried under vacuum, and used for the analysis described in the following.

\section{Protein concentration and amino acid composition}

Total amount of protein was analysed by the Dumas method [15] using a Thermo Scientific ${ }^{\mathrm{TM}}$ FLASH 2000 CHNS/O Analyzer. Amino acid composition, including alanine, arginine, aspartic acid, cysteine, glutamic acid, glycine, histidine, isoleucine, leucine, lysine, methionine, phenylalanine, proline, serine, threonine, tyrosine, and valine, was determined at a certified laboratory (Eurofins Food \& Agro Testing Sweden AB, Linköping, Sweden) by ion-exchange chromatography according to the method by Llames and Fontaine [16].

\section{Fatty acid methyl ester (FAME) content analysis}

The lyophilised algal biomass was treated with methanolic $\mathrm{H}_{2} \mathrm{SO}_{4}(2 \% \mathrm{v} / \mathrm{v})$ for $60 \mathrm{~min}$ at $90{ }^{\circ} \mathrm{C}$. Fatty acid methyl esters (FAME) were then extracted with hexane and analysed by combined gas chromatography and mass spectrometry (GCMS; Agilent 6890 GC and 5975 MS-Agilent Technologies, Santa Clara, CA, USA). The GC was equipped with a $60 \mathrm{~m}$ fused silica capillary column (ID $0.25 \mathrm{~mm}$ ) coated with HP5MS UI (Agilent Technologies). Aliquots comprising $2 \mu \mathrm{L}$ of sample were injected by an auto-injector (Agilent 7683B; Agilent Technologies) at $250{ }^{\circ} \mathrm{C}$. The $\mathrm{GC}$ oven was programmed at $125^{\circ} \mathrm{C}$ for $2 \mathrm{~min}$, followed by an increase of $4{ }^{\circ} \mathrm{C} \mathrm{min}{ }^{-1}$ up to $250{ }^{\circ} \mathrm{C}$ and isothermal for $10 \mathrm{~min}$, and a post-run cleaning of the column at $275^{\circ} \mathrm{C}$ for $1 \mathrm{~min}$. The mass spectra were generated at $70 \mathrm{eV}$, acquiring data over $\mathrm{m} / \mathrm{z} 29-400$ at a scanning rate of 1.99 scans s$^{-1}$. For quantification, heptadecanoic acid was added before esterification as an internal standard. Samples without the addition of heptadecanoic acid were also prepared, since the presence of this fatty acid has been reported in some strains of Arthrospira [17]. The amounts of FAME in the samples were based on total ion chromatogram (TIC) peak area with exception of the non-separating $\mathrm{C} 18: 1, \mathrm{C} 18: 2$, and $\mathrm{C} 18: 3$, and the amounts of which were determined by quantification of molecular ions, using extracted ion chromatograms.

\section{Determination of phycocyanin}

The lyophilised samples were mixed with phosphate buffer, $\mathrm{pH} 7$, using the method described by Chainapong et al. [18]. The equations based on spectrophotometric readings at 618 and $650 \mathrm{~nm}$ described by Kursar and Alberte [19] were applied to the results.

\section{Cadmium content}

Lyophilised Spirulina biomass produced in Spirulina medium, in effluent-based medium and also the freezedried filtered effluent was wet-combusted in $\mathrm{HNO} 3(65 \%)$ using a microwave technique. The concentration of cadmium in the samples was analysed by the commercial laboratory LMI AB, Sweden using analytical method SS 028150-2 based on ICP-MS, detection limit $0.1 \mu \mathrm{g} \mathrm{L}^{-1}$.

\section{Statistical analysis}

Each experiment was carried out in triplicate and repeated once, and mean values and standard deviation (SD) are reported. The data were analysed by analysis of variance followed by Tukey's multiple comparison test. Differences were considered significant at $P<0.05$ (Minitab, version 16).

\section{Results}

\section{Biomass production}

As shown in Fig. 1, the biomass production observed in the effluent-based medium was equal to that in Spirulina medium during the first 6 days. Thereafter, a decrease in 
biomass was observed in the effluent-based medium, whereas the amount of biomass in Spirulina medium remained stable. The $\mathrm{pH}$ increased to a higher value between day 3 and day 7 during growth in the effluentbased medium.

\section{Biochemical composition}

\section{Protein concentration and amino acid profile}

Total concentration of protein, expressed as $\%$ of DW, in the biomass harvested after 6 days of growth was $60.5 \pm 6.2$ and $63.3 \pm 2.7$ for Spirulina medium and effluent-based medium, respectively, and no significant differences were observed between the treatments. Table 1 shows the concentrations of individual amino acids in the biomass, with high concentrations of glutamic acid, aspartic, and leucine. No significant differences were observed in amino acid composition between the treatments.

\section{Fatty acid methyl ester (FAME) content analysis}

Total concentration of lipids in the biomass harvested after 6 days of growth was $34.8 \pm 3.8$ and $42.0 \pm 4.2 \mu \mathrm{g} \mathrm{mg} \mathrm{g}^{-1}$ DW for Spirulina medium and effluent-based medium, respectively, and no significant differences were observed between the treatments. Significant differences were observed in the fatty acid profile of the different treatments, as shown in Table 2. A slightly higher concentration of saturated fatty acids, mainly palmitic acid, was observed in the biomass produced in Spirulina medium than in the biomass produced in the effluent-based medium. The biomass produced in the effluent-based medium had slightly higher concentrations of the unsaturated fatty acids: palmitoleic acid and oleic acid. Heptadecanoic acid was not naturally present in the biomass, but 2-hydroxyheptadecanoic acid was detected in both treatments. Low concentrations of the long-chain fatty acids: arachidic acid and eicosatrienoic acid were also detected in the biomass.

\section{Determination of phycocyanin and allophycocyanin}

The concentration of the pigment phycocyanin differed significantly between Spirulina medium and the effluentbased medium $\left(63.3 \pm 11.7\right.$ and $86.2 \pm 1.9 \mathrm{mg} \mathrm{g}^{-1}$, respectively). For allophycocyanin, no significant

Table 1 Amino acid composition (g $100 \mathrm{~g}^{-1}$ protein, DW basis) of Spirulina (Arthrospira platensis) grown on Spirulina medium (SM) and on a medium based on filtered effluent from a biogas plant (BE)

\begin{tabular}{lll}
\hline Amino acid & SM & BE \\
\hline Alanine & $4.67 \pm 0.60$ & $4.53 \pm 0.37$ \\
Arginine & $3.96 \pm 0.54$ & $3.91 \pm 0.31$ \\
Aspartic acid & $6.05 \pm 0.68$ & $5.81 \pm 0.40$ \\
Cysteine & $0.43 \pm 0.05$ & $0.43 \pm 0.04$ \\
Glutamic acid & $8.08 \pm 0.91$ & $7.65 \pm 0.50$ \\
Glycine & $3.06 \pm 0.35$ & $2.99 \pm 0.24$ \\
Histidine & $0.99 \pm 0.14$ & $0.97 \pm 0.09$ \\
Isoleucine & $3.32 \pm 0.46$ & $3.23 \pm 0.28$ \\
Leucine & $5.35 \pm 0.66$ & $5.19 \pm 0.43$ \\
Lysine & $2.96 \pm 0.38$ & $2.91 \pm 0.26$ \\
Methionine & $1.41 \pm 0.19$ & $1.47 \pm 0.16$ \\
Phenylalanine & $2.83 \pm 0.33$ & $2.70 \pm 0.20$ \\
Proline & $2.24 \pm 0.20$ & $2.20 \pm 0.12$ \\
Serine & $3.24 \pm 0.30$ & $3.06 \pm 0.22$ \\
Threonine & $3.34 \pm 0.29$ & $3.23 \pm 0.28$ \\
Tyrosine & $2.55 \pm 0.35$ & $2.56 \pm 0.16$ \\
Valine & $3.75 \pm 0.52$ & $3.62 \pm 0.30$ \\
\hline
\end{tabular}

No significant difference was found between the treatments
Fig. 1 Growth $\left(\mathrm{g} \mathrm{L}^{-1}\right.$ dry weight, DW) of Spirulina (Arthrospira platensis) in effluent-based medium (BE) and in Spirulina medium (SM), and $\mathrm{pH}$ changes in the medium over time

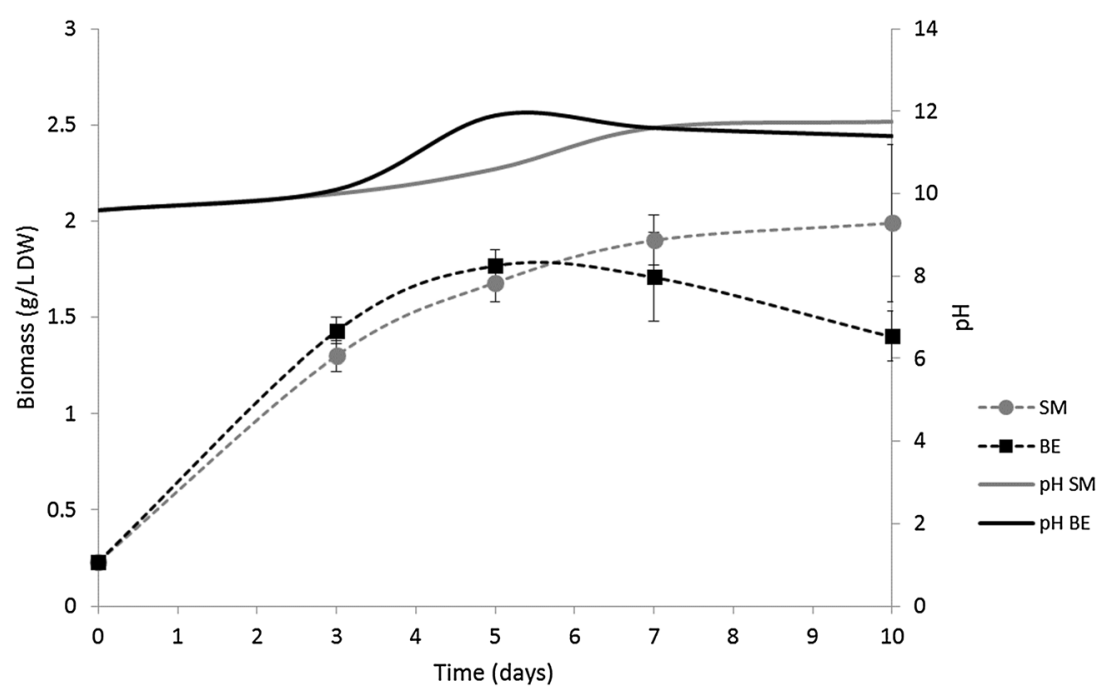


Table 2 Relative proportions of fatty acids (\% of total fatty acid amount) in biomass of Spirulina (Arthrospira platensis) when grown on Spirulina medium (SM) or on a medium based on filtered effluent from a biogas plant (BE)

\begin{tabular}{lll}
\hline Fatty acid & SM & BE \\
\hline $14: 0$ & $0.3 \mathrm{a}^{*}$ & $0.4 \mathrm{a}$ \\
$15: 0$ & $0.4 \mathrm{a}$ & $0.3 \mathrm{a}$ \\
$16: 0$ & $42.8 \mathrm{a}$ & $38.6 \mathrm{~b}$ \\
$16: 02 \mathrm{OH}$ & $0.5 \mathrm{a}$ & $0.2 \mathrm{a}$ \\
$16: 1$ & $2.8 \mathrm{a}$ & $4.5 \mathrm{~b}$ \\
$17: 02 \mathrm{OH}$ & $2.3 \mathrm{a}$ & $3.3 \mathrm{~b}$ \\
$17: 1$ & $0.1 \mathrm{a}$ & $0.4 \mathrm{~b}$ \\
$18: 0$ & $5.3 \mathrm{a}$ & $3.4 \mathrm{a}$ \\
$18: 1$ & $8.8 \mathrm{a}$ & $10.2 \mathrm{~b}$ \\
$18: 2$ & $26.9 \mathrm{a}$ & $28.7 \mathrm{a}$ \\
$18: 3$ & $9.8 \mathrm{a}$ & $9.7 \mathrm{a}$ \\
$20: 0$ & $0.06 \mathrm{a}$ & $0.1 \mathrm{a}$ \\
$20: 3$ & $0.04 \mathrm{a}$ & $0.2 \mathrm{~b}$ \\
$\Sigma$ SFA & 51.6 & 46.3 \\
$\Sigma$ UFA & 48.4 & 53.7 \\
\hline
\end{tabular}

* Values within rows followed by different letters are significantly different $(P<0.05$, Tukey's test $)$

difference in concentration was observed $(37.1 \pm 7.4$ and $41.3 \pm 2.1 \mathrm{mg} \mathrm{g}^{-1}$, respectively).

\section{Cadmium content}

Cadmium concentration was below the detection limit in the biomass produced in Spirulina medium. However, in the biomass produced in the effluent-based medium, the cadmium concentration was $0.07 \pm 0.05 \mathrm{mg} \mathrm{kg}^{-1} \mathrm{DW}$. The filtered effluent used in the study had a cadmium concentration of $0.36 \pm 0.01 \mathrm{mg} \mathrm{kg}^{-1} \mathrm{DW}$.

\section{Discussion}

This study shows that the anaerobic digestate effluent produced during the biogas process can be used for production of Spirulina. Compared with the Spirulina medium, which is optimized considering both nutrient composition and buffer capacity, equal biomass production was observed until late exponential phase. Furthermore, there were no significant differences in protein amount and amino acid composition of the biomass produced between the treatments. The total amount of protein and the amino acid composition observed agree well with previous findings $[2,20]$ and confirm the potential of Spirulina as a source of high-quality protein. The total amount of lipids was slightly, although not significantly, higher in the biomass produced in the effluent-based medium. Some differences in lipid composition were observed between the different treatments, with a slightly higher concentration of unsaturated fatty acids in the biomass produced in the effluent-based medium. Overall, the lipid composition agreed well with previous findings on this strain [17], with a dominance of palmitic acid followed by linoleic acid.

The nutrient concentration and quality differed widely between the treatments and the decline in biomass observed in the stationary phase in the effluent-based medium could possibly have been avoided if a higher nutrient level had been applied. However, adding the filtered effluent in the amount needed to reach the nutrient concentrations present in Spirulina medium is not an option for cultivation of phototrophic organisms, since the effluent from the biogas process is characterised by high turbidity and high ammonia content [21]. Both these parameters have a negative effect on photosynthesis, turbidity by decreasing penetration of light, and ammonia by an uncoupling effect on the photosynthesis process [22]. A significant increase in phycocyanin concentration in the effluent-based medium was observed in the present study and might be related to the higher turbidity compared with Spirulina medium. Phycocyanin has a role as an accessory pigment and increased production could have been a physiological response to the lower amount of light. Similarly, Jung et al. [23] who used extracts from oyster shells and soil as an amendment to Zarrouk's medium during cultivation of Spirulina (A. maxima) observed a significant increase in phycocyanin concentration when the extract was added.

The ammonium concentration in anaerobic effluent has also been demonstrated to be a limiting factor in trials on use of digestate in hydroponic plant cultivation [24, 25]. To enable a higher nutrient concentration to be provided, ammonia stripping and nitrification has been used as a means to avoid ammonia toxicity at low dilution levels of digestate [26]. Furthermore, nitrification of anaerobic effluent has been shown to lead to rapid sedimentation of suspended solids, providing a clear, yellowish liquid [27]. This would be desirable to avoid turbidity during Spirulina cultivation. Moreover, the high $\mathrm{pH}$ applied for cultivation of Spirulina can be expected to cause considerable ammonia volatilisation, similar to the ammonia emissions issue reported for soil fertilisation with digestate [28]. Nitrification pre-treatment would mitigate these emissions through decreasing the ammonia:nitrate ratio, but might lead to substantial emissions of nitrous oxide during bacterial oxidation of ammonia [29].

The cyanobacteria generally have high environmental tolerance and are able to use a wide range of nitrogen sources, including ammonium, nitrate, and organic compounds, such as amino acids, with ammonium as the preferred nitrogen source [30]. In the present study, in 
Spirulina medium, nitrogen was supplied as nitrate in an initial concentration of $412 \mathrm{mg} \mathrm{L}^{-1}$, whereas in the effluent-based medium, nitrogen was mainly supplied as ammonium in a total concentration of $93 \mathrm{mg} \mathrm{L}^{-1}$. The amount of protein in Spirulina biomass has been reported to be affected by the nitrogen concentration [31]. However, this was not observed in the present study, where there was no difference in either crude protein content or amino acid composition between the treatments. As pointed out by Markou and Georgakakis [4], contradictory results have been reported concerning the effect of nitrogen concentration on the quantity and quality of lipids in Spirulina biomass. In the present study, a slight increase in total amount of lipids was observed in the biomass produced in the effluent-based medium. However, phosphorus was supplied in a considerably lower amount in the effluentbased medium $\left(4 \mathrm{mg} \mathrm{L}^{-1}\right)$ than in the optimized medium (89 $\mathrm{mg} \mathrm{L}^{-1}$ ), which could have affected this result, because $\mathrm{P}$ (and $\mathrm{N}$ ) deficiency has been reported to increase lipid production in macroalgae [32].

The presence of potential contaminants and their risk of transmission into the food chain is an important parameter to consider in all residue-based processes. In the present study, the cadmium concentration was below the detection limit in the biomass produced in Spirulina medium. However, in the biomass produced in the effluent-based medium, the cadmium concentration was $0.07 \pm 0.05 \mathrm{mg} \mathrm{kg}^{-1} \mathrm{DW}$. The filtered effluent used in the study had a cadmium concentration of $0.36 \pm 0.01 \mathrm{mg} \mathrm{kg}^{-1} \mathrm{DW}$. Pollution of the environment by heavy metals due to industrial and agricultural activities is well documented and has occurred worldwide over the past two centuries [33]. It should also be pointed out that there are soils, e.g., alum shale, with a naturally high concentration of heavy metals, such as cadmium, which adds to the final soil cadmium concentration [34]. The concentration of heavy metals in the effluent from biogas production will vary depending on the substrates used in the process [9]. In Sweden, the concentration of cadmium in effluent from the biogas process is monitored and a range of $0.3-0.6 \mathrm{mg} \mathrm{kg}^{-1}$ dry matter is commonly reported [35]. The concentration in the biogas effluent used in the present study $\left(0.36 \pm 0.01 \mathrm{mg} \mathrm{kg}^{-1}\right.$ DW) was within this range. Microalgae and also the cyanobacterium Spirulina are known to have a high capacity for accumulation of heavy metals in their biomass [36]. Accumulation of cadmium was confirmed in the present study, with a mean concentration of $0.07 \pm 0.05 \mathrm{mg} \mathrm{kg}^{-1}$ Spirulina dry matter produced in the effluent-based medium, whereas the concentration was below the detection limit for the biomass produced in Spirulina medium. However, the amount of cadmium observed in the biomass produced in the effluent-based medium was still considerably below the established threshold for food [37].
From the present study, it can be concluded that the effluent from the biogas process sustained good growth of Spirulina and, what is more important, that the quality of the biomass was high. As pointed out by de Groot and Bogdanski [9], there is increasing interest in anaerobic digestion of farm and household residues, e.g., smallholder biogas digesters and community biogas plants can be found worldwide. An interesting future scenario is, therefore, to integrate Spirulina production into the biogas plant. Simplified Spirulina production techniques, similar to simplified hydroponic techniques promoted for increased food security and economic stability in poor urban areas [38], could be developed and integrated with small-scale lowcost biogas plants. This scenario implies a need for identifying and using other residue streams from the process, such as residual heat. As demonstrated in the present study, the heavy metal concentration in the biogas slurry is an important parameter to control. It should also be pointed out that the components used in the effluent-based medium in the present study were not subjected to any kind of disinfection or sterilisation treatment, which would facilitate establishment of a large-scale process.

Acknowledgements This study was funded by Carl Trygger's Foundation for Scientific Research, which is gratefully acknowledged.

\section{Compliance with ethical standards}

Conflict of interest The authors declare that they have no conflict of interest.

Open Access This article is distributed under the terms of the Creative Commons Attribution 4.0 International License (http://crea tivecommons.org/licenses/by/4.0/), which permits unrestricted use, distribution, and reproduction in any medium, provided you give appropriate credit to the original author(s) and the source, provide a link to the Creative Commons license, and indicate if changes were made.

\section{References}

1. Vonshak A (1997) Spirulina platensis (Arthrospira): physiology, cell biology and biotechnology. In: Vonshak A (ed) Taylor and Francis, London

2. Habib MAB, Parvin M, Huntington TC, Hasan MR (2008) A review on culture, production and use of Spirulina as food for humans and feeds for domestic animals and fish. FAO, Rome (Circular 1034; ISSN 2070-6065)

3. Vonshak A, Laorawat S, Bunnag B, Tanticharoen M (2014) The effect of light availability on the photosynthetic activity and production of outdoor cultures of Arthrospira platensis (Spirulina). J Appl Phycol 26:1309-1315

4. Markou G, Georgakakis D (2011) Cultivation of filamentous cyanobacteria (blue-green algae) in agro-industrial wastes and wastewaters: a review. Appl Energy 88:3389-3401 
5. Cordell D, Drangert JO, White S (2009) The story of phosphorus: global food security and food for thought. Global Environ Change 19:292-305

6. Usharani G, Saranraj P, Kanchana D (2012) Spirulina cultivation: a review. Int J Pharm Biol Arch 3:1327-1341

7. Chojnacka K, Noworyta A (2004) Evaluation of Spirulina sp. growth in photoautotrophic, heterotrophic and mixotrophic cultures. Enzyme Microb Technol 34:461-465

8. Patil V (2007) The relevance of biofuels. Curr Sci 92:707

9. de Groot L, Bogdanski A (2013) Bioslurry = The brown gold. A review of scientific literature on the co-product of biogas production. Environment and natural resources management working paper 55, FAO (ISSN 2226-6062)

10. Qi X, Zhang S, Wang Y, Wang R (2005) Advantages of the integrated pig-biogas-vegetable greenhouse system in North China. Ecol Eng 24:177-185

11. Feng T, Cheng S, Min Q, Li W (2009) Productive use of bioenergy for rural household in ecological fragile area, Panam County, Tibet in China: the case of the residential biogas model. Renew Sustain Energy Rev 13:2070-2078

12. Morais MG, Alberto J, Costa V (2007) Biofixation of carbon dioxide by Spirulina sp. and Scenedesmus obliquus cultivated in a three-stage serial tubular photobioreactor. J Biotechnol 129:439-445

13. Cuellar-Bermudez SP, Garcia-Perez JS, Rittmann BE, ParraSaldivar R (2015) Photosynthetic bioenergy utilizing $\mathrm{CO}_{2}$ : an approach on flue gases utilization for third generation biofuels. J Clean Prod 98:53-65

14. Tel DA, Heseltine C (1990) The analysis of $\mathrm{KCl}$ soil extracts for nitrate, nitrite and ammonium using a TRAACS 800 analyzer. Commun Soil Sci Plant Anal 21:1681-1688

15. Bellomonte GA, Constantine S, Giammariolo N (1987) Comparison of modified automatic dumas method and the traditional Kjeldahl method for nitrogen determination in infant food. J Assoc Off Anal Chem 70:227-229

16. Llames CR, Fontaine J (1994) Determination of amino acids in feeds-collaborative study. J AOAC Int 77:1362-1402

17. Mühling M, Belay A, Whitton BA (2005) Variation in fatty acid composition of Arthrospira (Spirulina) strains. J Appl Phycol 17:137-146

18. Chainapong T, Traichaiyaporn S, Deming RL (2012) Effect of light quality on biomass and pigment production in photoautotrophic and mixotrophic cultures of Spirulina platensis. J Agr Technol 8:1593-1604

19. Kursar TA, Alberte RS (1983) Photosynthesis unit organization in red alga: relationships between light-harvesting pigments and reaction centers. Plant Physiol 72:409-414

20. Misurcova L, Bunka F, Ambrozova JV, Machu L, Samek D, Kracmar K (2014) Amino acid composition of algal products and its contribution to RDI. Food Chem 151:120-125

21. Noike T, Goo IS, Matsurmoto T (2004) Development of a new type of anaerobic digestion equipped with the function of nitrogen removal. Water Sci Technol 49:173-179

22. Crofts AR (1966) Uptake of ammonium ion by chloroplasts and the mechanism of amine uncoupling. Biochem Biophys Res Comm 24:127-134

23. Jung JY, Kim S, Lee H, Kim K, Kim W, Park MS, Kwon JH, Yang JW (2014) Use of extracts from oyster shell and soil for cultivation of Spirulina maxima. Bioprocess Biosyst Eng 37:2395-2400

24. Liedl BE, Cummins M, Young A, Williams ML, Chatfield JM (2004) Liquid effluent from poultry waste bioremediation as a potential nutrient source for hydroponic tomato production. In: VII International Symposium on Protected Cultivation in Mild Winter Climates: Production, Pest Management and Global Competition 659: 647-652

25. Liu WK, Du LF, Yang QC (2008) Biogas slurry added amino acid decrease nitrate concentrations of lettuce in sand culture. Acta Agric Scand Sect B 2:10-14

26. Kamthunzi WM (2015) The potential for using anaerobic digester effluents in recirculating hydroponics system for lettuce production. Malawi J Agr Nat Res Dev Stud 1:8-13

27. Botheju D, Svalheim O, Bakke R (2010) Digestate nitrification for nutrient recovery. Open Waste Manag 3:1-12

28. Nkoa R (2014) Agricultural benefits and environmental risks of soil fertilization with anaerobic digestates: a review. Agron Sustain Dev 34:473-492

29. Wolf U, Roland F, Höppner F, Flessa H (2014) Contribution of $\mathrm{N}_{2} \mathrm{O}$ and $\mathrm{NH}_{3}$ to total greenhouse gas emission from fertilization: results from a sandy soil fertilized with nitrate and biogas digestate with and without nitrification inhibitor. Nutr Cycl Agroecosys 100:121-134

30. Muro-Pastor MI, Reyes JC, Florencio FJ (2005) Ammonium assimilation in cyanobacteria. Photosynth Res 83:135-150

31. Sassano CEN, Gioielli LA, Ferreira LS, Rodrigues MS, Sato S, Converti A, Carvalho JCM (2010) Evaluation of the composition of continuously-cultivated Arthrospira (Spirulina) platensis using ammonium chloride as nitrogen source. Biomass Bioenergy 34:1732-1738

32. Sharma KK, Schuhmann H, Schenk PM (2012) High lipid induction in microalgae for biodiesel production. Energies 5:1532-1553

33. Monteiro CM, Castro PML, Malcata FX (2012) Metal uptake by microalgae: underlaying mechanisms and practical applications. Biotechnol Prog 28:299-311

34. Söderström M, Eriksson J (2013) Gamma-ray spectrometry and geological maps as tools for cadmium risk assessment in arable soils. Geoderma 192:323-334

35. Tekniska verken (2013) Naturvårdsverkets föreslagna gränsvärde för hållbar återföring av fosfor - en konsekvensanalys för biogasverksamheten inom Tekniska verken i Linköping $A B$ och Svensk Biogas AB. Tekniska verken i Linköping AB, Sweden (in Swedish)

36. Rangsayatorna N, Pokethitiyooka P, Upathamb ES, Lanzac GR (2004) Cadmium biosorption by cells of Spirulina platensis TISTR 8217 immobilized in alginate and silica gel. Environ Int 30:57-63

37. Commission Regulation (2006) (EC) No. 1881/2006 of 19 December 2006 setting maximum levels for certain contaminants in foodstuffs. https://www.fsai.ie/uploadedFiles/Consol_Reg1881_ 2006.pdf. Accessed 5 Apr 2016

38. Orsini F, Kahane R, Nono-Womdim R, Gianquinto G (2013) Urban agriculture in the developing world: a review. Agron Sustain Dev 33:695-720 